\title{
Study on the Modern Apprenticeship Talent Training Mode on the School-Enterprise Cooperation Platform
}

\author{
Guangli Ren \\ Department of Navigational Technology, Tianjin Maritime College, Tianjin, 300350, China \\ rrggll@163.com
}

Keywords: school enterprise cooperation, modern apprenticeship, study, talent training mode

\begin{abstract}
On the basis of the research on the cooperation between schools and enterprises of marine major, this paper analyzes the advantages of implementing modern apprenticeship system, expounds the existing problems. Based on the above, this paper proposes to deepen the reform of talent training mode, innovate the curriculum system and the teaching content, create a double tutor system of talent cultivation mode, and finally solve the problem encountered in implementing modern apprenticeship system for marine majors.
\end{abstract}

\section{Introduction}

At present, the "modern apprenticeship training mode" in china is in its early stage. We cannot copy the development model of western country because of our country' situation, but create our own modern apprenticeship mode that is suitable for the law of development in our country and has socialism with Chinese-characteristics.

\section{The Advantages of Developing Modern Apprenticeship in Navigation Majors}

The research shows that China has a certain foundation and advantages to develop the "modern apprenticeship personnel training mode" based on the existing conditions.

\subsection{The Developing Direction has been Pointed out by the National Policy.}

Since 2014, China has been vigorously developing vocational education and actively promoting the reform and innovation of vocational education based on relevant guide lines. "The decision on accelerating the development of modern vocational education issued by the state department" has asked all departments and all relevant units to work together, hand in hand to strengthen the teaching fusion, promote school-enterprise cooperation so as to promote the development of vocational education in our country. The "work opinion on pilot implementation of modern apprenticeship" issued by the ministry of education has elaborated that the modern apprenticeship in the personnel training mode is the trend in the future. The ministry of education asked all departments to strengthen the organization, guide and encourage the enterprises and colleges to create the modern apprenticeship training platform by optimizing the allocation of resources. The ministry of education has also required local education bureaus and committees to strengthen policy support and promote the participating desire of schools and enterprises through the implementation and promotion of various incentives. The opinion also promises the students not worry about their social insurance, students' health and students' rights and interests. The Ministry of Human Resources and Social Development and The Ministry of Health decided to carry out pilot work in Beijing, Tianjin, Liaoning, Inner Mongolia and other places in August 11, 2015. The first "modern apprenticeship" pilot work units totally one hundred and sixty-five was published which was followed by the corresponding measures. The relevant Departments have issued various decisions and measures in a short time. We can see the emphasis and support strength of the government to promote the modern apprenticeship personnel training mode. Enterprises and colleges should actively participate in this movement to develop their innovative talent training mode, which will make it a new impetus for their development. 


\subsection{The Internal Environment of the College can be Reasonably Utilized.}

Modern maritime vocational education has changed from the mode emphasizing the theory to the mode emphasizing both the theory and practice, especially practice. In this case, it can adapt to the modern enterprise talent demand. This vocational education mode change provides ample internal power for the implementation of the modern apprenticeship. The government's guidance and policy support is the catalyst for colleges to carry out the modern apprenticeship. Related departments have launched a series of preferential measures such as teaching allowance, welfare, income distribution, scientific research funds, teacher' evaluation to improve the enthusiasm of the teachers in colleges. College teachers and industry experts develop their subjective initiative. It will certainly promote the deep cooperation between colleges and enterprises and ensure the sustainable development of the modern apprenticeship talent training mode. This mode can guarantee basic wages, the personal safety of the students during the apprentice, safeguard the rights and interests of students and can greatly improve the students' recognition and participation. It can also guarantee the number of the modern apprenticeship training students not decrease. Thus, the colleges have accumulated enough soil and nutrients for the growth of modern apprenticeship.

\section{3 "Double Qualification" Teachers can Provide Early Manpower Support.}

Due to the particularity of this major, most maritime vocational colleges have developed the "Double Qualification" teacher team at an early time. The maritime management department will audit the qualification of the teacher team who participate in training seafarers. Every teacher training seafarers have to work at sea at least a period of time corresponding to the training seafarer's rank, otherwise they should not work as a trainer. Therefore, maritime vocational colleges has its natural human resource advantages to develop modern apprenticeship training. Tianjin maritime college, for example, there are 109 teachers with "double qualifications" among 243 full-time teachers, which accounted for 44.9\%. Furthermore, among the 109 teachers, there are more than 60 teachers have worked as a seafarer onboard a vessel, which accounted for more than $25 \%$, including a number of captains, chief engineers. In addition, the college has actively engaged in improving the teaching level by recruiting a lot of practice skillful experts from the industry who have a good reputation for part-time teaching. The two kinds of teachers above mentioned have worked for many years in large enterprises and ships, with abundant practical experience to be a master as well as a teacher. Powerful "Double Qualification" teacher team provides human resource guaranteeing for the modern apprenticeship training mode. The college and enterprise can build a teacher team based on the powerful human resources. This manner breaks the existing system of choose and employ persons, and removes the barriers of professional identity. This manner has also provide an entrance between enterprise experts and college teachers, which makes talents be truly "Double Qualification", the latest "Double Qualification" and "Double Qualification" forever.

\subsection{The Existing School Enterprise Cooperation is a good Development Platform.}

The successful development of talent cultivation mode of modern apprenticeship cannot be achieved without the close cooperation of colleges, enterprises and government departments. Many vocational colleges have carried out cooperation of school and enterprises for many years although their developing level isn't the same. Cooperation of school can be used and promoted as an existing platform. After years of groping and practice, Tianjin Marine College has achieved fruitful results in the cooperation of school and enterprises, because all departments are actively engaged in cooperate with enterprises. Marine department is more successful, because it has built a number of practice base with Huayang marine service center, Henanwanzheng ocean ship management co., LTD., Tianjin Tianheng maritime inspection co., LTD. These practice base can train the school student and the enterprise staff. Based on this cooperation, the department has set up the enterprise order cultivation, which is personalized teaching according to the characteristics of the enterprise. The curriculum setting and teaching arrangement of the order cultivation can meet the individual demand of each enterprise on the base of meeting the requirement of the college. Over the years, the marine department has cultivated a lot of graduated students who is rich of practice experience, 
professional quality and professional ethics for the company, which has got a good reputation in this vocation. This model of education, which is innovated on the platform of school-enterprise cooperation, is the prototype of modern apprenticeship training mode. Other vocational colleges like Tianjin Marine College has its inherent advantages during the development of modern apprenticeship training mode on the basis of deepening the cooperation of school and enterprises.

\section{The Problems of Modern Apprenticeship in the Development of Marine Major}

In the process of research, some problems are also found. The modern apprenticeship system with Chinese characteristics will come a long way only after we have research and settle these problems.

\subsection{The Guidance of Excessive Administration Restricts the Development From Professional Education to Vocational Education.}

Modern apprenticeship is a highly professional and advanced talent cultivation mode covering the whole process of study, internship and employment. Modern apprenticeship talent training mode must treat schools and enterprises as an organic whole, which requires a loose policy environment and a wide market environment. And this must be done throughout the time and space. A number of colleges and universities have encountered a policy barriers because they didn't develop a good relations with government in the process of building modern apprenticeship talent training mode. Without the policy support, their construction of teacher team will not be strong enough and their building fund will not be enough as while. After the design of the top level by the government, the subsequent policies cannot keep up. This problem will cause the school's talent training progress more or less slower than the market demand.

In addition, the vocational colleges are under the dual leadership and supervision of the education bureau and the maritime bureau which are not affiliated to each other. The education bureau is good at teaching management and is more professional in education methods, but it is often formalism. The Marine bureau is concerned with reality, but has no experience on education. The degree of integration of these institutional mechanisms precisely determine the level of development of marine vocational education.

\subsection{Teachers' Theoretical Research Ability and Practical Ability Cannot Complement Each Other.}

The study found that some colleges and universities rely upon teachers who are lack of real practice of production but have high educational level and rich knowledge in their theoretical education. Practical teaching is held by an enterprise master. The teaching is limited to the level of combination of theory and practice. The continuing education of teachers cannot be concerned about by the colleges, which leads to solid theoretical teachers can't get the practice exercise. On the other hand, rich practical experience teachers can't keep pace to update their knowledge in time. This will make some colleges and universities become sclerotic and directionless in their education.

\subsection{Institutions Have Insufficient Funds and Government Serve Insufficient Support.}

Tianjin Maritime College, for example, although the college is the largest maritime vocational colleges in Beijing-Tianjin-Hebei region, but the college does not have its own training ship so far. The college cannot carry out practical teaching onboard ship. What they can do is to use a variety of simulator instead, so that the practice effect is not ideal.

In the current economic environment, the training ship can get few short-term rewards. Institutions cannot afford to training ship financially alone in this case, on the other hand, the institutions are not willing to buy training ship. In this case, local government should strive to support marine vocational education development based on the long-term view and sustainable development of the region. 


\subsection{The Propaganda of Modern Apprenticeship is Inadequate, the Students and Parents Doubt about this New Type of Talent Training Mode.}

Students and parents are not fully understand the modern apprenticeship training mode, so they don't trust the new talent training mode. They think it will narrow the scope of employment in the future. There are also some parents think that there are safety dangers in the internship, which lead some students to resist the modern apprenticeship system.

\section{Countermeasures and Suggestions}

Through collecting data, the author summarizes relevant literature on the basis of the analytical synthesis. The author investigates the situation of school-enterprise cooperation in higher vocational colleges and analyze the existing problems. This paper also discusses the implementation of modern apprenticeship in marine vocational colleges and put forward the following countermeasures.

\subsection{Government Agencies Should Issue the Implementation Documents that Promote the Work of Modern Apprenticeship.}

Government policy guidance and macro-control play a key role in the reform of education or the promotion of modern apprenticeship. With the issue of "the ministry of education on modern apprenticeship pilot work opinion", the relevant departments have established supporting policy and encourages enterprises to participate in many aspects to explore and establish the system of social responsibility report. With the top-level design strategy of modern vocational education, it will greatly inspire enterprises to participate in modern talent cultivation with large enthusiasm, initiative and creativity.

\subsection{The School Should Strengthen "Double Qualification" Teacher Team.}

In the marine education, a good "double qualification" teacher should have the qualifications for teachers in colleges, positional titles, senior officer certificate of competency (such as the captain, chief engineer) and have the relevant work experience at sea. Such a person can be a teacher with practical experience in school and a crewman with a theoretical knowledge in the enterprise.

Teachers in higher vocational colleges must meet a higher requirement and qualification. The tutors and masters in school-enterprise cooperation platform must be professional in solid theoretical foundation and practical ability so as to meet the requirements of various subjects and students guidance work. The efficiency and the enthusiasm of the students will be developed. The students may regards their teachers as occupation mentor even life idol because of their knowledge and experience.

\subsection{The School Should Adapt to the Modern Apprenticeship Concerning the Establishment and Perfection of the Teaching Management System.}

Specifically, college should carry out positional titles evaluation work according to the particularity of maritime professional as well as the enterprises work experience of the teachers. In this case, good teachers will be attracted. The colleges should formulate relevant policies to guide and encourage officers especially senior captain, chief engineer to get involved in the modern apprenticeship work so as to exert their professional, practical advantages.

\subsection{Establish the Students' Professional View Correctly and Increase the influence of Modern Apprenticeship System.}

The school and enterprises should cooperate closely to guide students to form a correct professional outlook, and carry out colorful vocational training to help students plan their own career. The colleges should introduce as many as successful cases in teaching so as to inspire students' love and recognition of their major and industry, such as outstanding graduates. The colleges should strengthen curriculum reform, update the training equipment timely, and increase the practicability and interest of teaching, so that the students can join in actively. 


\section{Conclusion}

Through collecting data, this paper summarizes relevant literature on the basis of the analytical synthesis. The author investigates the situation of school-enterprise cooperation in vocational colleges and analyze the existing problems. To sum up, after thinking about the modern apprenticeship teaching mode in marine vocational colleges, we can be innovative in talent cultivation mode so as to ensuring that marine vocational colleges can advance modern apprenticeship based on the platform of school-enterprise cooperation.

\section{References}

[1] Kong Xiangfeng. Research on modern apprenticeship talent cultivation mode in navigation technology specialty. [J]. Nautical education research. 2017(2).

[2] Wang Hui, Liu Jing; Wang Yumiao. The combination of apprentice and higher vocational education based on American experience and revelation. [J]. Foreign education research. 2017(4).

[3] $\mathrm{Wu}$ Jianshe. The five problems that need to be solved in developing modern apprenticeship system in higher vocational education. [J]. Research of higher education. 2014(7)

[4] Jiang Bian; Xiaoyu Wang. Study of Talents Training Mode of Modern Apprenticeship in the Higher Vocational Education. [J]. Proceedings of 2017 the 3rd International Symposium on Social Science (ISSS 2017).

[5] Jiang Ningning. Exploration and Practice of the Training Model of Modern Apprenticeship. [J]. Research of higher education. Joint Journal of Tianjin Vocational College. 2017(10) 